УДК 51-74:669.017.3

О.Ю. Клочко, к.т.н., докторант, klochko.hntysh@gmail.com

Харківський національний технічний університет сільського господарства ім. П. Василенка

\title{
МАТЕМАТИЧНЕ МОДЕЛЮВАННЯ МЕТАЛОГРАФІЧНОГО ЗОБРАЖЕННЯ ЗА ДОПОМОГОЮ РІШЕННЯ ГРАНИЧНИХ ЗАДАЧ ДЛЯ РІВНЯННЯ ЛАПЛАСУ
}

У роботі розглянуті нові підходи до побудови комп'ютерних моделей металографічної гетерогенної структури шляхом математичного моделювання за допомогою рішення граничних задач для рівняння Лапласа, які з досить високою точністю дозволяють одержувати зображення структур з урахуванням дифузійних процесів, щз протікають при їхньому формуванні. Дослідження проводили шляхом побудови моделей утворення структур складних гетерофазних сплавів (на прикладі валкових високохромистих чавунів), на які впливає велика кількість складних процесів, подібних гідродинамічним.

Ключові слова: математична модель, гетерогенна структура, граничні умови, рівняння Лапласа.

In the present paper we describe the new approaches for construction of computer models of metallographic heterogeneous structure using mathematical modeling and solving Laplace equation boundary problems, which allow one to obtain the high-accuracy images of structures. In our research we take the diffusion processes that occur during structure formation into account. Our research has been carried out by modeling the structure formation of the complex heterophase alloys (e.g., high-chromium cast iron rolls) affected by a large number of complex processes similar to the hydrodynamic ones.

Keywords: mathematical model, heterogeneous structure, boundary conditions, Laplace equation.

\section{Постановка проблеми}

Найважливішим завданням при розробці нових прогресивних технологій є використання матеріалів з необхідним комплексом властивостей, досягти який можливо шляхом реалізації необхідного структурно-фазового стану об'єкта. Для досягнення поставленої задачі необхідно адекватне розуміння впливу складних процесів структуроутворення на структуру і властивості, в тому числі складнолегованих залізовуглецевих сплавів, що враховують умови експлуатації. Одним із шляхів отримання цієї інформації, є попереднє моделювання та дослідження такого впливу, в тому числі побудова моделей при мінливості металографічних структур, які враховують вплив різних зовнішніх факторів, наприклад, технологічних параметрів виробництва, таких як, температурні режими при кристалізації і термообробці. Від точності побудови і аналізу таких моделей залежить достовірність і об'єктивність вирішення завдань контролю і управління технологічними процесами виплавки та обробки металів, а також, в подальшому, можливість підвищення експлуатаційної стійкості готового виробу.

\section{Аналіз останніх джерел досліджень і публікацій}

Граничні задачі для рівнянь 3 частинними похідними в областях 3 незв'язної кордоном (якими можна розглядати мікроструктури металевих сплавів) відіграють важливу роль в теорії багатьох механічних і фізико-хімічних процесів, що відбуваються в гетерогенних середовищах [1]. У різні роки був запропонований цілий ряд як чисельних, так і аналітичних методів вирішення цих крайових задач [2-5].

\section{Мета роботи}

Побудова моделей утворення структур складних гетерофазних сплавів (на прикладі валкових високохромистих чавунів), на які впливає велика кількість складних процесів, подібних гідродинамічним, використовуя метод математичного моделювання за допомогою рішення граничних задач для рівняння Лапласа. 


\section{Матеріали досліджень}

При дослідженні використовували металографічні фотографії мікроструктур валкових високохромистих чавунів (16-18\% Cr, 2.7-3.0\% C).

\section{Результати досліджень та їх обговорення}

Задаючи різні граничні умови, проводили моделювання, вирішуючи рівняння Лапласа у внутрішніх областях, заданих зображенням мікроструктури. В результаті, знаходили значення умовних кольорів і їх розподіл, проводячи при цьому порівняння з розподілом умовних кольорів металографічного зображення оригінальної структури.

Для отримання гістограми розподілу умовних кольорів реального металографічного зображення, був застосований підхід 3 використанням розробленої методики оптикоматематичного аналізу фаз. Ця методика заснована на гідродинамічних аналогіях із застосуванням рівнянь Нав'є-Стокса, що описують формуванні фаз (за рахунок дисипації енергії в результаті дифузійних процесів $[6,7])$. Відповідно були використані поняття вихору, який обчислюється через лапласіан при числовий обробці фотографій. Оцінку проводили, відповідно до розташування обчислюваних значень на зображенні металографічної структури, оцифрованому в формат .bmp. 3 метою більшої наочності і зменшення машинного часу оцінки використовували двовимірну модель. Значення лапласіану розраховували згідно [7], шляхом вирішення диференційного рівняння функції струму (Пуассона)

$$
L(x, y) \equiv \Delta=\frac{\partial^{2} c}{\partial x^{2}}+\frac{\partial^{2} c}{\partial y^{2}} .
$$

Обчислення проводили, використовуючи метод кінцевих різниць. Досліджуване зображення розбивали на області розміром $n \times l$ пікселя, де в кожній точці $C(x, y)(x$ і $y$ - координати розглянутої точки) обчислювали значення лапласіану.

Наприклад, для області розміром $3 \times 3$ пікселя $C(x, y)$ в кінцево-різницевому поданні матриця має вигляд:

$$
C=\left(\begin{array}{ccc}
c_{i-1, j-1} & c_{i-1, j} & c_{i-1, j+1} \\
c_{i, j-1} & c_{i, j} & c_{i, j+1} \\
c_{i+1, j-1} & c_{i+1, j} & c_{i+1, j+1}
\end{array}\right) .
$$

В качестве элемента матрицы приняли пиксель изображения $c_{m, n}$, являющийся кодом условного цвета при оцифровке фотографии (где $m=i-1, i, i+1$ - номер строки, $n=j-1, j, j+1-$ номер столбца). Обработку такой матрицы выполняли путем последовательного сканирования каждого ее пикселя, задавая его как среднюю точку $c_{i, j}$, находящуюся внутри ячейки заданного размера $(3 \times 3)$. При этом $L(x, y)$ в конечно-разностном представлении имеет вид:

В якості елемента матриці взяли піксель зображення $c_{m, n}$, що $€$ кодом умовного кольору при оцифруванні фотографії (де $m=i-1, i, i+1-$ номер рядка, $n=j-1, j, j+1$ - номер стовпця). Обробку такої матриці виконували шляхом послідовного сканування кожного ії пікселя, задаючи його як середню точку $c_{i, j}$, що знаходиться всередині області заданого розміру $(3 \times 3)$. При цьому $L(x, y)$ в кінцево-різницевому поданні має вигляд:

$$
\Delta \equiv L \approx \frac{\Delta^{2} c}{\Delta x^{2}}+\frac{\Delta^{2} c}{\Delta y^{2}}=L_{i, j}=c_{i, j-1}+c_{i-1, j}+c_{i, j+1}+c_{i+1, j}-4 c_{i, j},
$$

де шаг по координатам на цифровому зображенні $\Delta x=\Delta y=1$.

Моделювання проводили шляхом вирішення наступної варіаційної задачі. На підставі граничні умов, що задаються, шляхом вирішення диференціальних рівнянь в частинних похідних (рівнянь Лапласа), відповідних 


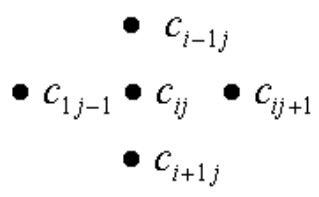

Рис 1. Схема розташування групи з 5 пікселів, що моделюють вихор, на фрагменті розміром $3 \times 3$ пікселі

$$
\frac{\partial^{2} c}{\partial x^{2}}+\frac{\partial^{2} c}{\partial y^{2}}=0
$$

методом ітерацій в кінцево-різницевому вигляді [8-10], знаходили коди умовного кольору внутрішніх точок кожного обраного фрагмента. Гістограма розподілу яких збігалася $з$ розподілом кодів умовного кольору оригінального зображення.

Згідно (3), кінцево-різницеве вираження лапласіану задавали формулою, що складається з 5-х складових, а самі точки були представлені на схемі, рис. 1, в яких частинні похідні по осях $x$ та $y$ знаходили за формулами:

$$
\begin{gathered}
\Delta_{x} c=c_{i, j-1}-c_{i, j}, \\
\Delta_{x}^{2} c=c_{i, j-1}-c_{i, j}-\left(c_{i, j}-c_{i, j+1}\right)=c_{i, j-1}-2 c_{i, j}+c_{i, j+1}, \\
\Delta_{y} c=c_{i-1, j}-c_{i, j}, \\
\Delta_{y}^{2} c=c_{i-1, j}-c_{i, j}-\left(c_{i, j}-c_{i+1, j}\right)=c_{i-1, j}-2 c_{i, j}+c_{i+1, j},
\end{gathered}
$$

де код умовного кольору в точці $c_{i, j}$, обчислювали за формулою:

$$
c_{i, j}=\frac{c_{i, j-1}+c_{i, j+1}+c_{i-1, j}+c_{i+1, j}-L}{4} .
$$

Якщо через $k$ позначити номер ітерації, то представлена формула служить наближенням наступної $k+1$ ітерації рівняння Лапласу (4):

$$
c_{k+1, i, j}=\left(c_{k, i, j-1}+c_{k, i, j+1}+c_{k, i-1, j}+c_{k, i+1, j}-L\right) / 4 .
$$

Перепишемо цю формулу в наступному виді:

$$
c_{i, j}^{k+1}=\frac{c_{i, j-1}^{k}+c_{i, j+1}^{k}+c_{i-1, j}^{k}+c_{i+1, j}^{k}-L}{4} .
$$

Проведені розрахунки показали, що рішення такого ітераційного рівняння може мати максимуми і мінімуми в граничних точках, що необхідно враховувати. Для виключення такого результату розрахунки виробляли 3 декількома варіантами завдання граничних умов. При цьому домагалися мінімального відхилення від фактичного розподілу кольорів на оригінальному зображенні.

У першому варіанті - граничні умови задавали контуром фрагменту розміром $25 \times 25$ пікселя. Тоді 3625 пікселів, що входять в обраний фрагмент, умовний колір контуру задавали, приблизно, на 100. На пікселях всередині фрагмента за нульову (початкову) ітерацію колір задавали довільно (як 255 - білий колір, або - код умовного кольору відповідних структурних складових [11]). На кожен фрагмент задавали по 100 ітерацій.

У другому варіанті граничні умови задавали на вертикальних лініях аналогічно першому варіанту — через 25 пікселів, а на горизонтальних — групами по 5 пікселів, що моделюють вихор, розташований в фрагментах розміром $3 \times 3$ (див. рис. 1 ).

Для вирішення задачі моделювання структур, 3 урахуванням інтенсивних процесів структуроутворення, наприклад, при кристалізації, був застосований третій варіант завдання граничних умов, відповідний перестановці випадковим чином у внутрішніх областях зображення. У їх якості було використано групи по 5 пікселів (див. рис. 1), що моделюють вихор, де для кожної точки задавали значення лапласіану.

Розглянуто зіставлення моделей, згідно з різними варіантами. Як приклад, оцінимо модель, отриману із завданням першого варіанту граничних умов. При цьому, розрахунок за основною ітераційною формулою (11) виконували тільки для внутрішніх точок області. Якщо внутрішня точка поряд 3 границею, то, принаймні, одна (для кутових точок 2-і) належить граничної області і цей факт враховували тим, що в правій частині розрахункової ітераційної фор- 


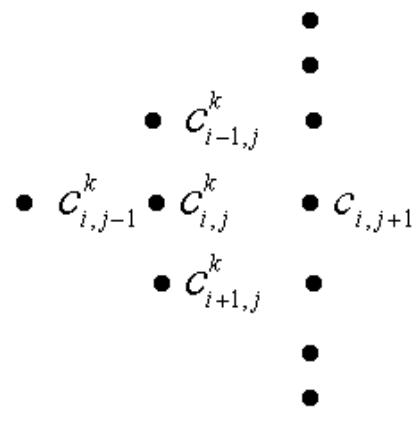

Puc. 2. Розташування приграничних пікселів біля правої вертикальної границі

мули (11) на відповідне місце підставляли граничне значення коду умовного кольору. Як нульову (початкову) ітерацію при $k=0$ приймали білий колір

$$
c_{i, j}^{0}=255 \text {. }
$$

Наприклад, на рис. 2 представлена границя, що знаходиться праворуч від розрахункової внутрішньої точки $c_{i, j}^{k}$. Згідно зі схемою для пікселів, представлених тут, ітераційна формула має вигляд:

$$
c_{i, j}^{k+1}=\frac{\left(c_{i, j-1}^{k}+c_{i, j+1}+c_{i-1, j}^{k}+c_{i+1, j}^{k}-L\right)}{4},
$$

де $c_{i, j+1}$ без верхнього індексу $k$, оскільки точка взята из граничного значения.

Аналогічно, для приграничних точок у лівій вертикальній границі

$$
c_{i, j}^{k+1}=\frac{\left(c_{i, j-1}+c_{i, j+1}^{k}+c_{i-1, j}^{k}+c_{i+1, j}^{k}-L\right)}{4} .
$$

У верхній границі

$$
c_{i, j}^{k+1}=\frac{c_{i, j-1}^{k}+c_{i, j+1}^{k}+c_{i-1, j}^{k}+c_{i+1, j}-L}{4} .
$$

У нижній границі

$$
c_{i, j}^{k+1}=\frac{c_{i, j-1}^{k}+c_{i, j+1}^{k}+c_{i-1, j}+c_{i+1, j}^{k}-L}{4} .
$$

Зрозуміло, що для приграничних кутових точок $є$ ще 4 ітераційні формули без двох верхніх індексів:

Правий верхній кут

$$
c_{i, j}^{k+1}=\frac{c_{i, j-1}^{k}+c_{i, j+1}+c_{i-1, j}^{k}+c_{i+1, j}^{k}-L}{4} .
$$

Правий ніжній кут

$$
c_{i, j}^{k+1}=\frac{c_{i, j-1}^{k}+c_{i, j+1}+c_{i-1, j}+c_{i+1, j}^{k}-L}{4} .
$$

Лівий верхній кут

Лівий нижній кут

$$
c_{i, j}^{k+1}=\frac{c_{i, j-1}+c_{i, j+1}^{k}+c_{i-1, j}^{k}+c_{i+1, j}-L}{4} .
$$

$$
c_{i, j}^{k+1}=\frac{c_{i, j-1}+c_{i, j+1}^{k}+c_{i-1, j}+c_{i+1, j}^{k}-L}{4} .
$$

При виборі коду умовного кольору для завдання граничного контуру, слід враховувати, що для рівняння Лапласа найбільше та найменше значення рішення належить границі області [8]. Тому очевидно, що якщо прийняти в якості границі - кольори пікселів контуру всієї фотографії, то в отриманому рішенні не буде областей зображення, характерних для даної металографічної структури.

На рис. 3 представлені моделі зображень мікроструктур валкового високохромистого чавуну. При побудові математичних моделей розбивали фотографію на досить дрібні квадратні фрагменти розміром $25 \times 25$ пікселів. Використовували 1-й варіант завдання граничних умов, в 
якості яких задавали кольори границь фрагментів. Відповідно, при такій постановці, до граничних відносили 98 пікселів. При цьому, в першому рядку наведено зображення оригінальних мікроструктур. При моделюванні було проведено 100 ітерацій, де другий рядок (з індексом «а») - моделі з кодом умовного кольору нульової ітерації, що збігається з оригінальною фотографією; третій рядок (з індексом «б») - 3 кодом умовного кольору 0-ої ітерації, що рівняється 255.

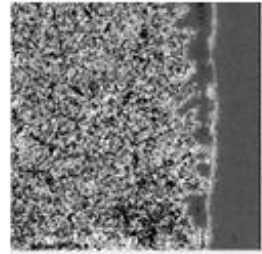

1

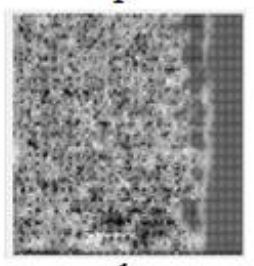

1.a

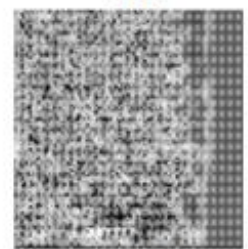

1.6

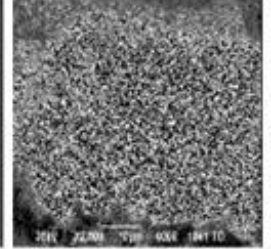

2

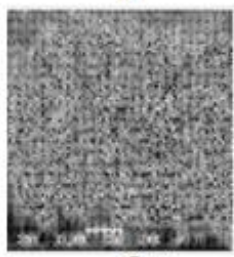

2.a

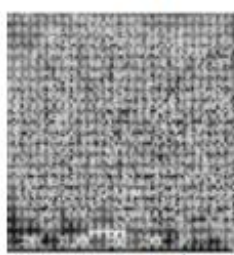

2.6

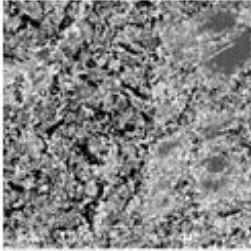

3

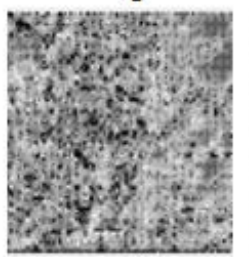

3.a

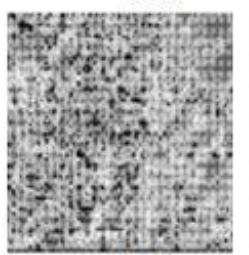

3.6

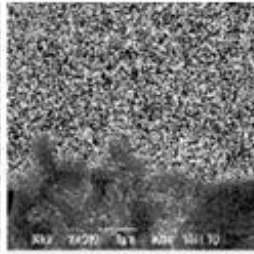

4

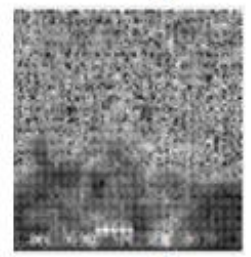

4.a

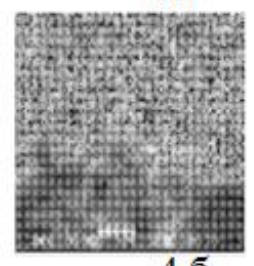

4.6
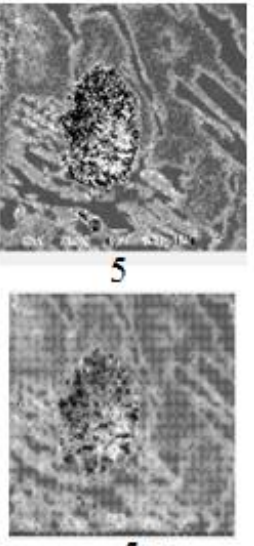

$5 . \mathrm{a}$

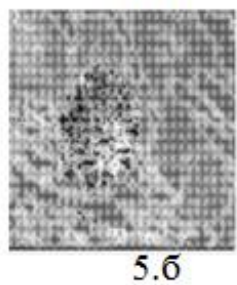

Puc. 3. Моделі мікроструктур високохромистого валкового чавуну при розбитті області зображення на фрагменти $25 \times 25$ пікселів і 31 -м варіантом граничних умов. $1-5-$ оригінальні фотографії; 1.a -5.a - моделі з кодом умовного кольору 0-ої ітерації, що збігається з оригінальною фотографією; 1.б - 5.6 - з кодом умовного кольору 0-ої ітерації, згідно (12)

Аналізуючи результати, встановлено, що якість отриманих моделей структур - задовільна. Однак на деяких моделях видно квадрати, що говорить про недостатньо точне рішення. При цьому подальше збільшення кількості ітерацій не привело до поліпшення якості зображення. Для усунення цього недоліку, при побудові моделі були задані інші граничні умови, відповідно другому варіанту: на вертикальних лініях через 25 пікселів, а на горизонтальних - точками (групами) по 5 пікселів, що входять у вихор (див. рис. 1). На рис. 4 представлені моделі мікроструктур високохромистого валкового чавуну при заданому другому варіанті граничних умов. При побудові таких моделей розбивали фотографію за запропонованою схемою. Було проведено 100 ітерацій. У першому рядку (номера $1-5)$ наведені зображення оригінальних мікроструктур, у другій (номера 1.a-5.a) - моделі з кодом умовного кольору нульовій ітерації рівній 255 при $k=0$.

Аналізуючи отримані моделі, можна стверджувати, що, в порівнянні з моделями, побудованими при заданому 1-му варіанті граничних умов, даний підхід дозволяє створити модель, 3 більш яскраво вираженою текстурою (див. рис. 3 (1.б-5.б) і рис. 4 (1.a-5.а)), що більш повно враховує анізотропію структурних складових гетерогенних сплавів. Однак при такому підході залишаються колишні недоліки у вигляді квадратів на зображенні, а також самі зображення виходять менш чіткими, ніж в першому варіанті.

Для поліпшення якості отриманої моделі, були використані граничні умови, що задаються всередині області зображення, що моделюється. У їх якості брали групи (вихори) по 5 пікселів (див. рис. 1), розкидані випадковим чином серед структури (третій варіант граничних умов). 


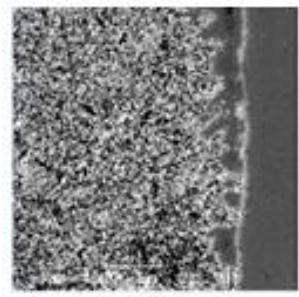

1

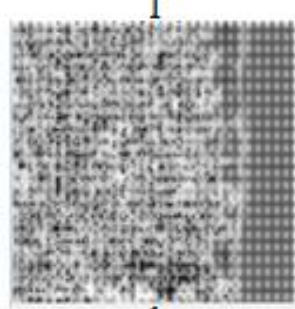

1.a

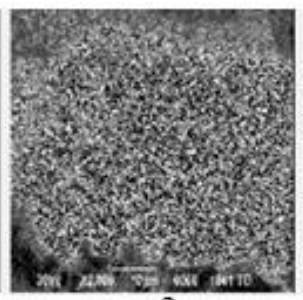

2

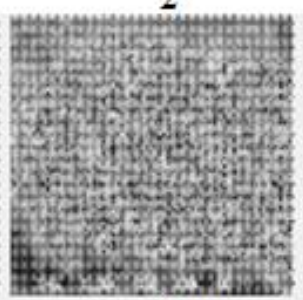

2.a

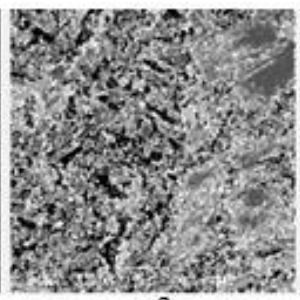

3

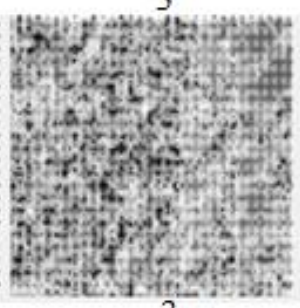

3.a

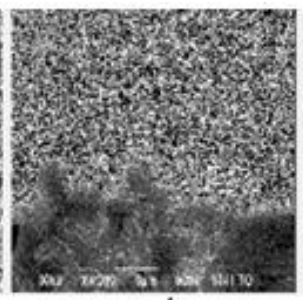

4

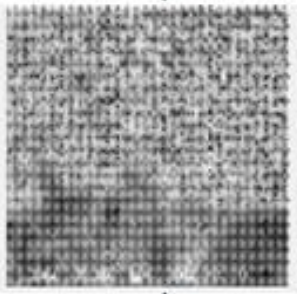

4.a
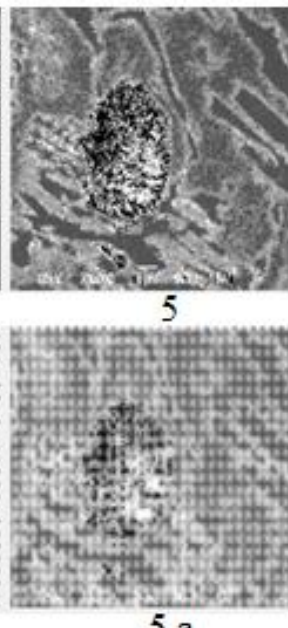

$5 . a$

Puc. 4. Моделі мікроструктур високохромистого валкового чавуну при заданому другому варіанті граничних умов: $1-5-$ оригінальні фотографії; 1.a - 5.a - моделі 3 кодом умовного кольору 0-ої ітерації, згідно (12)

В процесі виконання моделювання при завданні таких граничних умов, виникла необхідність у використанні додаткової, керуючої, матриці. У ній негативні значення лапласіанів для пікселів, крім тих, що входять у вихор, перебували на тих же місцях, що і на оригінальному зображенні. Алгоритм вирішення такого завдання з моделювання включав розрахунок ітерації за формулою (11). Поряд 3 викликом кодів 5-ти кольорів із матриці ітерацій, програма додатково розглядала умовні кольори $c_{i, j}, c_{i, j-1}, c_{i, j+1}, c_{i-1, j}, c_{i+1, j}$ П'яти елементів з керуючої матриці.

Якщо, в результаті виконання програми, елемент з індексом $c_{i, j}$ керуючої матриці був невід'ємним, то його відносили до внутрішньої границі, і розрахунок по ітераційної формулі (11) не виробляли. В іншому випадку розраховували наступну ітерацію по цій формулі. Попередньо аналізували на знак решти 4-х елементів ітераційної матриці $c_{i, j-1}, c_{i, j+1}, c_{i-1, j}, c_{i+1, j}$.

Якщо якийсь із них був невід'ємним, то в ітераційну формулу (11) вправу частину вносили елемент 3 керуючої матриці. Такий алгоритм повністю можна застосовувати щодо 8-ми описаних вище випадків (13)-(20) розташування пікселів уздовж обраної границі(приграничних). Наприклад, розглянемо на рис. 5 розташування обчислюваного вихору, який має верхні індекси i, того що знаходиться поруч з ним - граничного вихору без верхнього індексу. Це розташування відповідало б правому верхньому куту (див. формулу (13) і рис. 2) для попередніх граничних умов. На рис. 5 показані вісім точок, з яких - 3 з верхніми індексами, а 5 без нього, тобто, що належать внутрішньому граничному вихору. Відповідно, для цього випадку ітераційна формула виглядає так

$$
\begin{aligned}
& \bullet c_{i-2, j+1} \\
\bullet c_{i-1, j} & \bullet c_{i-1, j+1} \cdot c_{i-1, j+1} \\
\bullet c_{i, j-1}^{k} & \bullet c_{i, j}^{k} \\
& \bullet c_{i, j+1}^{k}
\end{aligned}
$$

Рис. 5. Приклад розташування граничного вихору і суміжного з ним розрахункового (без верхнього і з верхнім індексом $k$ відповідно)

$$
c_{i, j}^{k+1}=\frac{c_{i, j-1}^{k}+c_{i, j+1}+c_{i-1, j}+c_{i+1, j}^{k}-L}{4} .
$$

Аналогічно можна уявити і інші можливі сім випадків.

Можна припустити, що чим більше таких вихорів, тим краще буде збігатися розрахункова модель 3 оригіналом. Було проведено дослідження необхідної кількості випадково заданих вихорів (груп пікселів) для отримання якісної моделі. Встановлено, що якщо кількість таких випадково заданих груп (вихорів) неменше від 1/9 числа точок на фотографії, то розрахунковий 
рисунок і оригінал структури досить добре збігаються. При меншій кількості вихорів на розрахунковому рисунку залишаються зайві білі плями.

Було проведено дослідження, про те, як подібне моделювання впливає на зміну параметрів, що описують дифузійні процеси в системі, яка оцінює середню абсолютну узагальнену величину лапласіану і середню потужність дисипації енергії $[12,13]$. Для цього були побудовані випадково згенеровані зображення з різними гістограмами розподілу умовних кольорів, що імітують металографічні структури, з групами по 5 пікселів (моделюючими вихори) невпорядковано розташованими в їх внутрішніх областях (рис. 6, 1-й і 3-й рядки). Далі було проведено моделювання, шляхом випадкової перестановки таких груп (рис. 6, 2-й та 4-й рядки). В результаті моделювання при використанні заданого алгоритму, внаслідок тільки перестановки вихорів, середній код умовного кольору не змінювався.

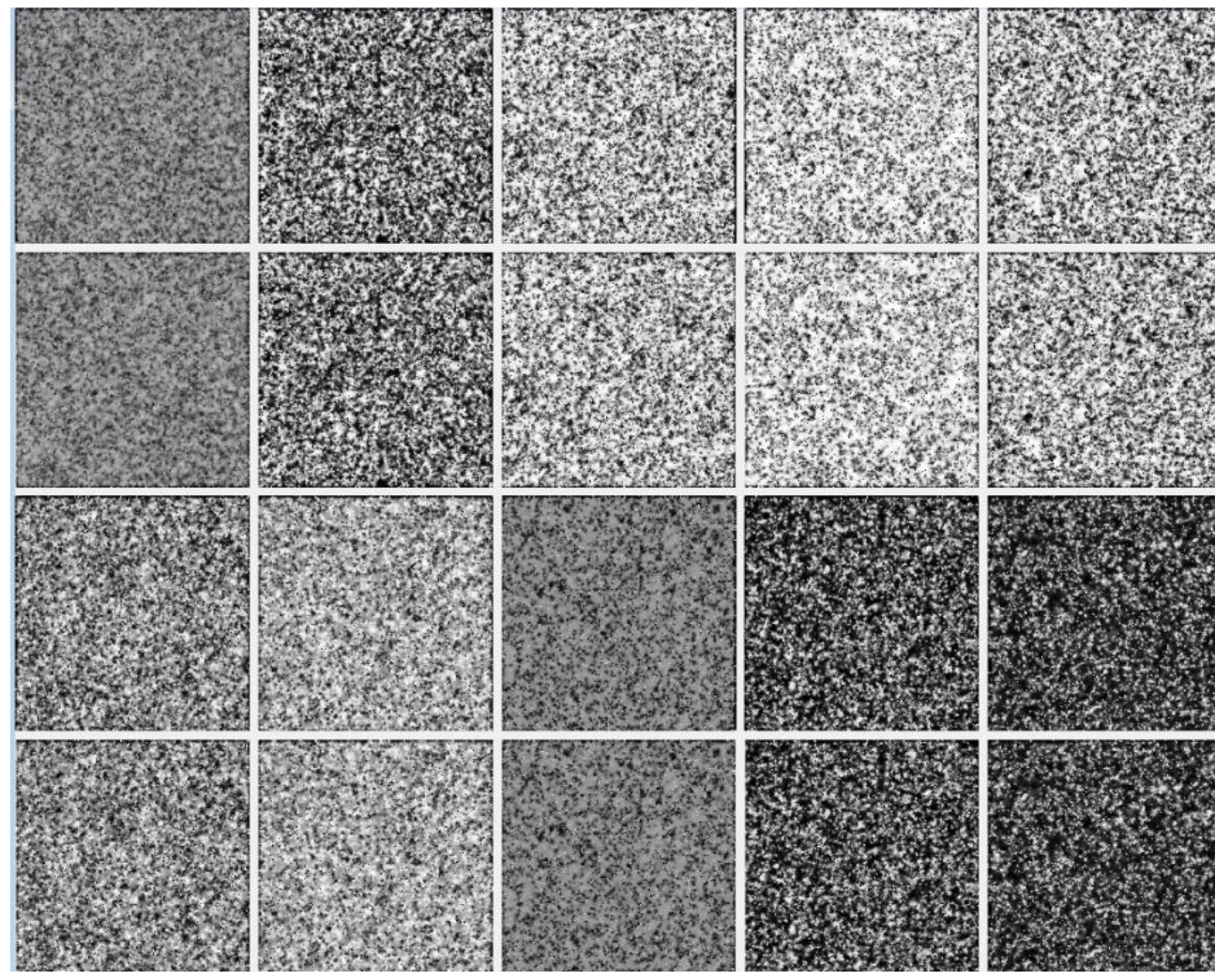

Рuc. 6. Зображення, що імітують металографічні структури, з групами з вихорами невпорядковано розташованими в їх внутрішніх областях (1-й і 3-й рядки) та їхні моделі, що отримані шляхом випадкової перестановки таких груп (2-й та 4-й рядки)

Разом з цим, відбулася зміна середніх величин абсолютного узагальненого лапласіану і потужності дисипації енергії (табл.1). Після проведеного моделювання їх величина зросла $~$ в 3 і 2 рази відповідно. Отримані результати свідчать про неповну відповідність гістограми розподілу умовних кольорів до і після такого моделювання. Для усунення цього недоліку рекомендується звужувати області гістограм, відкидаючи коди умовного кольору, які були задані для груп пікселів, що моделюють вихори в граничних умовах.

Керуючись наведеним вище, з урахуванням рекомендованого кількості груп, були представлені моделі реальних мікроструктур високохромистого валкового чавуну при заданому третьому варіанті граничних умов в порівнянні з оригінальними фотографіями (рис. 7). При моделюванні випадковим чином на зображення вводили групи (вихори) по п'ять пікселів, для яких код умовного кольору (9) змінювали, задаючи різні значення лапласіану. Число таких пікселів, які задавали граничні умови, відповідало $\mathrm{m} \times \mathrm{n} /$ кількість груп (вихорів), де $m \times n-$ число 
пікселів на всьому зображенні. Для даних моделей при розрахунках задавали 20, 25, 30 і 35 груп (вихорів) відповідно. Всього було проведено 100 ітерацій, де код умовного кольору нульовій ітерації $(k=0)$ був рівним 255.

Таблиия 1. Зміна середніх величин абсолютного узагальненого лапласіану i потужності дисипації енергії в результаті моделювання з третім варіантом граничних умов

\begin{tabular}{|c|c|c|c|c|c|c|}
\hline \multirow{3}{*}{$\begin{array}{l}\text { Номер } \\
\text { моделі }\end{array}$} & \multicolumn{6}{|c|}{ Середня величина } \\
\hline & \multicolumn{2}{|c|}{$\begin{array}{c}\text { коду кольору вихрю при } \\
\text { моделюванні }\end{array}$} & \multicolumn{2}{|c|}{$\begin{array}{c}\text { абсолютного узагальненого } \\
\text { лапласіану }\end{array}$} & \multicolumn{2}{|c|}{$\begin{array}{c}\text { потужності дисипаці } \\
\text { енергії }\end{array}$} \\
\hline & до & после & до & после & до & после \\
\hline 1 & 125 & 125 & 6 & 47 & 354 & 2817 \\
\hline 2 & 122 & 122 & 30 & 109 & 8847 & 15184 \\
\hline 3 & 163 & 163 & 48 & 111 & 15782 & 17776 \\
\hline 4 & 182 & 182 & 47 & 102 & 15319 & 16996 \\
\hline 5 & 157 & 157 & 35 & 107 & 10502 & 16057 \\
\hline 6 & 132 & 132 & 35 & 93 & 10829 & 12515 \\
\hline 7 & 156 & 156 & 24 & 81 & 6434 & 9756 \\
\hline 8 & 115 & 115 & 12 & 56 & 1449 & 4869 \\
\hline 9 & 87 & 87 & 24 & 96 & 6741 & 12426 \\
\hline 10 & 76 & 76 & 26 & 88 & 6756 & 12101 \\
\hline
\end{tabular}

В перших рядках (номери 1-5) приведені зображення оригінальних мікроструктур; у других (номери 1.а-5.a) - моделі з кількістю, заданих у випадкових місцях вихрив, рівних 20; в третіх (номери 1.б-5.б)-25; в четвертих (номери 1.в-5.в) - 30; в п'ятих (номера 1.г-5.г) -35 .

Слід зазначити, що при побудові моделі з використанням третього типу граничних умов, все ітерації проводили відразу для всього зображення розміром $\mathrm{m} \times \mathrm{n}$ пікселів, а не для кожного окремого фрагмента, наприклад, $25 \times 25$, як при побудові моделі із завданням граничних умов 1 і 2 виду. Вочевидь, що такий підхід, хоча незначно збільшує час машинної обробки, разом $з$ тим дозволяє повністю виключити істотні недоліки попередніх підходів - наявності квадратів на зображенні змодельованої структури.

Аналіз отриманого підходу показав, що він найбільш точно дозволяє моделювати складні гетерогенні структури, оскільки враховує турбулентний характер дифузійних процесів (завдання граничних умов у вигляді вихорів всередині області зображення), що протікають при структуроутворенні в результаті різних впливів, в тому числі і фаз, що кристалізуються в області високих температур.

Разом з тим встановлено, що якість зображення не поліпшується прямо пропорційне кількості таких випадково заданих груп (вихорів). Наприклад, спостерігається значне погіршення якості моделі при кількості вихорів, що рівна рівним 30 -ти (див. рис. 7, 1.в-5.в). Спостерігається поява значного числа білих плям.

Хоча подальше збільшення кількості таких груп, сприяє підвищенню якості моделі, що свідчить про необхідність подальшого вдосконалення такого методу.

Разом $з$ тим, виходячи з розглянутих моделей, очевидно, що перестановка вихорів відповідає, в більшій мірі, фізичної моделі і дає можливість, для гетерогенних металографічних структур, враховувати вплив процесів дифузії в результаті різних складних впливів, наприклад, таких як використання термообробки, а також магнітних і радіаційно-термічних впливів. 

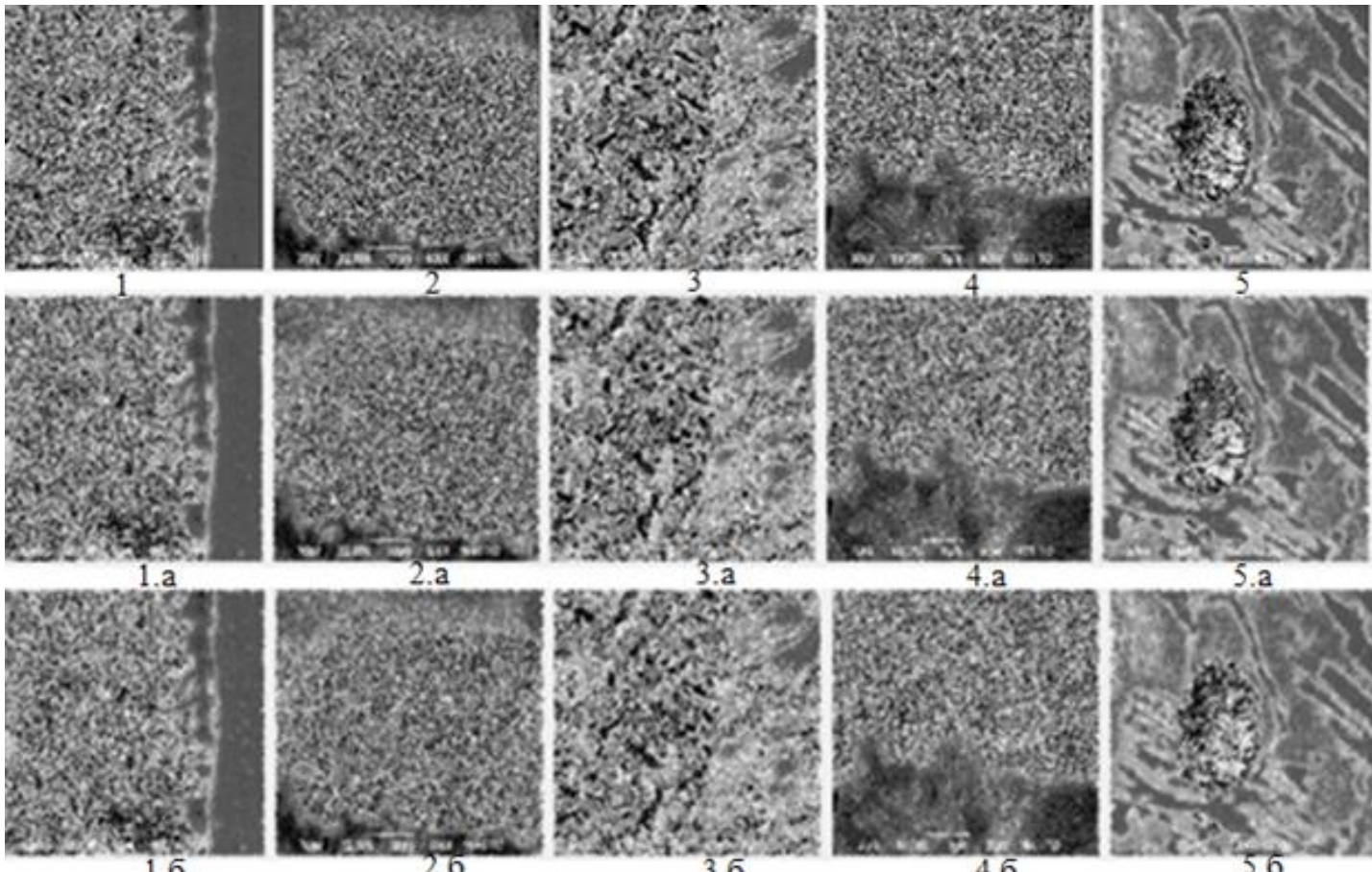

4. 2

$5 . \mathrm{a}$
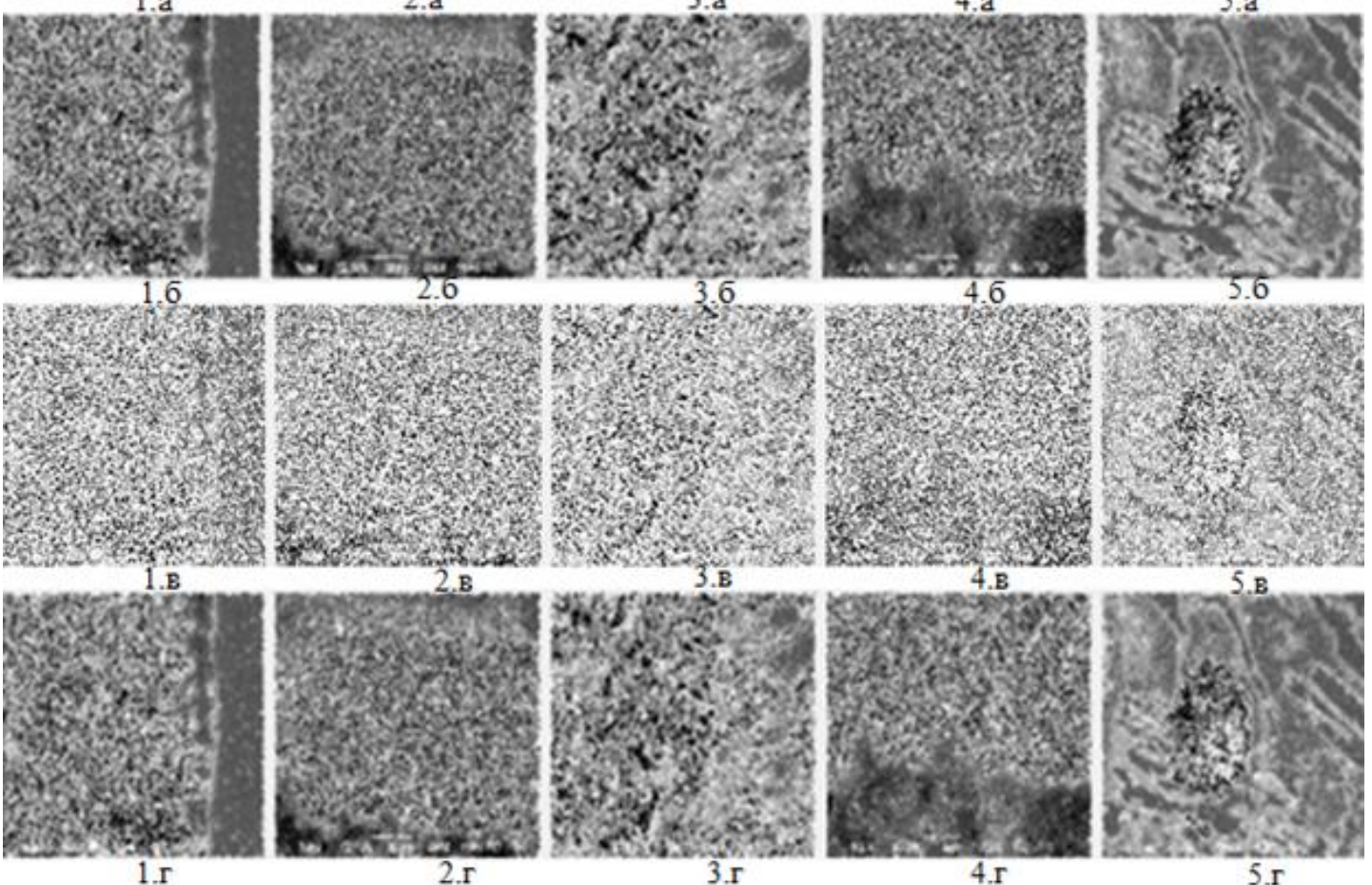

Рuc. 7. Порівняння реальних мікроструктур високохромистого валкового чавуну і їх моделей при заданому третьому варіанті граничних умов: $1-5$-оригінальні фотографії; моделі 3 кількістю, вихорів, що дорівнює: $1 . \mathrm{a}-5 . \mathrm{a}-20 ; 1.6-5.6-25 ; 1 . \mathrm{B}-5 . \mathrm{B}-30$; 1. г-5.г -35

\section{Висновки}

Запропоновано методики побудови комп'ютерних моделей металографічної структури шляхом математичного моделювання за допомогою рішення граничних задач для рівняння Лапласа, які з досить високою точністю дозволяють отримувати зображення структур з урахуванням дифузійних процесів, що протікають при їх формуванні.

Автор висловлює щиру вдячність Бєлкіну Ю.Л. і Скобло Т.С. за допомогу і участь в проведенні досліджень і обговоренні статті.

\section{Список використаної літератури}

1. Ладыженская О.А. Краевые задачи математической физики. М.: «Наука», 1973, 407 с.

2. Бажал И.Г., Куриленко О.Д. Перекристаллизация в дисперсных системах. Киев, Наукова думка, 1975, $216 \mathrm{c.}$ 
3. Brailsford A.D., Bullough R. The theory of sink strengths. Philos. Trans. R. Soc. London, Ser. A, 1981, v. 302, p. 87-137.

4. Calef D.F., Deutch J.M. Diffusion- controlled reactions. Ann. Rev. Phys. Chem., 1983, v. 34, p. 493-524.

5. Згаевский В.Э., Яновский Ю.Г. Вычисление эффективной вязкости концентрированных суспензий жестких частиц на основе кристаллической модели. Механика композиционных материалов и конструкций, 1996, т. 2, № 1, с. 137-167.

6. Traitak S.D. Methods for solution of boundary value problems for regions with multiply connected boundaries // J. Composite Mech. Design, Vol. 9, № 4 (2003), P. 495-521.

7. Patrick J. Roache. Fundamentals of Computational Fluid Dynamics. Publisher: Hermosa Pub, $1998,648 \mathrm{p}$.

8. Скобло Т.С., Белкин Е.Л., Клочко О.Ю. Обоснование применения понятий уравнений гидродинамики Навье-Стокса для анализа металлографических изображений. / Сб. трудов конф. «Европейская наука XXI века», 07-15 мая 2011 г., Польша.

9. Пикулин В.П., Похожаев С.И. Практический курс по уравнениям математической физики. Пиксел, 2013. - 208 с.

10.Беккенбах Э.Ф. Современная математика для инженеров. Рипол Классик, 2013, 506 с.

11.Васидзу К. Вариационные методы в теории упругости и пластичности. М: Мир, 1987, 542 с.

12.Skoblo T.S., Klochko O.Yu., Belkin E.L. Structure of high-chromium cast iron // Steel in Translation. - March 2012, Volume 42, Issue 3, pp 261-268.

13.Методика моделирования структуры металлов с помощью перестановки пикселей изображения / Т.С. Скобло, О.Ю. Клочко, Е.Л. Белкин // Вісник ХНТУСГ. - Випуск 115, 2011. C. $10-21$.

14.Математический анализ оценки дисперсности структуры легированных чугунов / Т.С. Скобло, О.Ю. Клочко, Е.Л. Белкин, А.И. Сидашенко // Сталь. - 2017. - № 2. - С. 51-54. 